Check for updates

Cite this: Chem. Commun., 2022, 58,673

Received 2nd November 2021, Accepted 9th December 2021

DOI: $10.1039 / \mathrm{d} 1 \mathrm{cc} 06182 \mathrm{~h}$

rsc.li/chemcomm

\section{Triple-decker complexes incorporating three distinct deck architectures $\dagger$}

\author{
Xiaofei Sun, (D) ${ }^{a}$ Akhil Kumar Singh, ${ }^{a}$ Ravi Yadav, (D) ${ }^{a}$ Da Jin, ${ }^{a}$ Maria Haimerl, ${ }^{b}$ \\ Manfred Scheer (D) ${ }^{b}$ and Peter W. Roesky (D) *a
}

The reactivity of the dilithioplumbole $\left(\left[\mathrm{Li}_{2}(\mathrm{thf})_{2}\left(\mu, \eta^{5}-\mathrm{L}^{\mathrm{Pb}}\right)\right], \mathrm{L}^{\mathrm{Pb}}=1,4-\right.$ bis-tert-butyl-dimethylsilyl-2,3-bis-phenyl-plumbolyl) towards the reactive pnictogen precursors $\mathrm{P}_{4}$, pentaphosphaferrocene, and pentaarsaferrocene $\left(\left[C p * F e\left(\eta^{5}-E_{5}\right)\right]\left(C p^{*}=\eta^{5}-C_{5} M e_{5}, E=P, A s\right)\right)$ is reported. The reaction with $\mathrm{P}_{4}$ afforded a phospholyl lithium complex, via lead-phosphorus exchange, while the reactions with $\left[\mathrm{Cp} * \mathrm{Fe}\left(\eta^{5}-\mathrm{E}_{5}\right)\right]$ yielded the first examples of $\mathrm{Pb}-\mathrm{Fe}-\mathrm{Li}$ heterotrimetallic triple-decker polypnictogenides with three different deck motifs.

Since the milestone discovery of ferrocene in $1951^{1}$ and bis(benzene)chromium in $1955,{ }^{2}$ the chemistry of organometallic sandwich complexes has become an intensive subject of research, not only owing to their unique structural features but also due to their interesting physical and chemical properties. ${ }^{3}$ Most of the sandwich complexes contain carbocyclic ligands, among which, the cyclopentadienyl $\left(\mathrm{Cp}=\eta^{5}-\mathrm{C}_{5} \mathrm{H}_{5}\right)$ anion and its derivatives have become the most frequently used ones. ${ }^{4}$ The possibility of expanding the dimension of sandwich complexes was achieved in 1972 by Salzer and Werner when they isolated the first triple-decker complex $\left[\mathrm{Ni}_{2} \mathrm{Cp}_{3}\right]^{+} .{ }^{5}$ This was followed by a fast development of triple/multi-decker complexes comprising different ligand systems. ${ }^{6}$ However, such compounds with purely inorganic ring systems or heterocyclic ligands are still relatively unexplored compared to those with carbocylic ligand systems. The scarcity arises from the lack of suitable synthetic methods. The first successful stabilization of a cyclo- $\mathrm{E}_{5}(\mathrm{E}=\mathrm{As}, \mathrm{P})$ moiety as middle deck in triple-decker complexes was reported in 1982 $\left(\left[(\mathrm{CpMo})_{2}\left(\mu, \eta^{4}-\mathrm{As}_{5}\right)\right]\right)^{7}$ and in $1986\left(\left[\left(\mathrm{Cp}{ }^{*} \mathrm{Cr}\right)_{2}\left(\mu, \eta^{5}-\mathrm{P}_{5}\right)\right], \mathrm{Cp}^{*}=\eta^{5}-\right.$ $\left.\mathrm{C}_{5} \mathrm{Me}_{5}\right),{ }^{8}$ respectively. Due to the isolobal analogy between $\left[\mathrm{E}_{5}\right]^{-}$

\footnotetext{
${ }^{a}$ Institute of Inorganic Chemistry, Karlsruhe Institute of Technology (KIT), Engesserstraße 15, Karlsruhe, 76131, Germany.E-mail: roesky@kit.edu

${ }^{b}$ Institute of Inorganic Chemistry, University of Regensburg, Regensburg 93040, Germany

$\dagger$ Dedicated to Prof. Wolfgang Beck on the occasion of his 90th birthday. \$ Electronic supplementary information (ESI) available. CCDC 2119835-2119837. For ESI and crystallographic data in CIF or other electronic format see DOI: $10.1039 / \mathrm{d} 1 \mathrm{cc} 06182 \mathrm{~h}$
}

$(\mathrm{E}=\mathrm{P}, \mathrm{As})$ and $\mathrm{Cp}^{-},\left[\text {cyclo- }_{5}\right]^{-}$fragments have become potential ligands for inorganic sandwich complexes. The ferrocene analogues, pentaphosphaferrocene $\left[\mathrm{Cp} * \mathrm{Fe}\left(\eta^{5}-\mathrm{P}_{5}\right)\right]^{9}$ and pentaarsaferrocene $\left[\mathrm{Cp}{ }^{*} \mathrm{Fe}\left(\eta^{5}-\mathrm{As}_{5}\right)\right]{ }^{10}$ were successfully synthesized and their reactivity has been investigated in the recent years. ${ }^{11}$ As the parent ferrocene usually features an iron-centred redox behaviour with no significant structural changes, in contrast, for $\left[\mathrm{Cp}^{*} \mathrm{Fe}\left(\eta^{5}-\mathrm{E}_{5}\right)\right]$, due to the involvement of the $\left[\mathrm{E}_{5}\right]^{-}$moiety in redox reactions, their reactivities show greater variety and redox reactions are often accompanied by structural modification such as hapticity change. ${ }^{12}$ Due to their redox non-innocent nature towards low-valent species, they can act as excellent building blocks for multimetallic complexes. ${ }^{12 e, f, 13}$ However, only a handful of triple-decker complexes bearing $\left[\mathrm{Cp}^{*} \mathrm{FeE}_{5}\right](\mathrm{E}=\mathrm{P}, \mathrm{As})$ fragments have been reported to date (Fig. 1A). ${ }^{12 f, 14}$

Another possibility to generate heterometallic triple-decker complexes is to use heavy $\mathrm{Cp}$ analogues, which contain heavy group 14 metals in their $\pi$-skeleton. ${ }^{16}$ Those recently developed metalloaromatic species possess unique chemical and physical properties and therefore opened a new field for synthetic chemists. ${ }^{16 c}$ The group of Saito has accomplished the creation of novel $\mathrm{Rh}$ and $\mathrm{Ru}$ triple-decker complexes through salt metathesis reactions using the dianionic stannole ligand as middle deck (Fig. 1B and C). ${ }^{17}$ For the heaviest dianionic metallole, the plumbole, ${ }^{18}$ only anionic sandwich-type $\mathrm{Ru}$ and
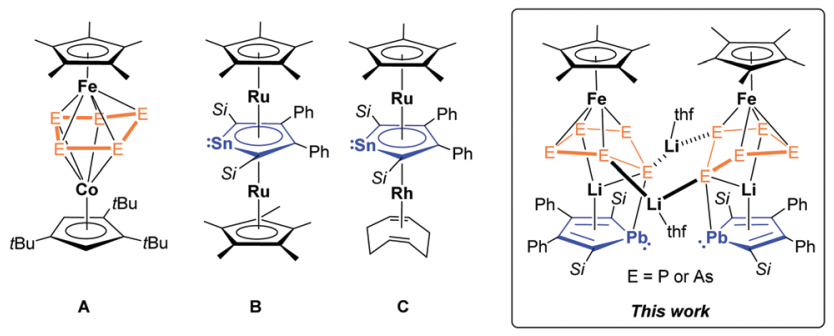

Fig. 1 Selected examples of heterometallic triple-decker complexes with non-carbocyclic ligands $\left(\mathrm{E}=\mathrm{P}\right.$ or $\left.\mathrm{As}, \mathrm{Si}=\mathrm{SitBuMe}_{2}\right){ }^{12 f, 14 a, b, d-f, 15}$ 


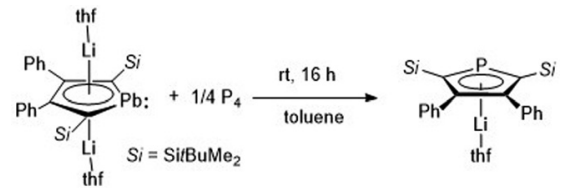

Scheme 1 Synthesis of complex 1

$\mathrm{Rh}$ complexes $\left[\mathrm{Li}\left(\mathrm{Cp}{ }^{*} \mathrm{Ru}\right)\left(\eta^{5}-\mathrm{L}^{\mathrm{Pb}}\right)\right]^{19}\left(\mathrm{~L}^{\mathrm{Pb}}=1,4\right.$-bis-tert-butyldimethylsilyl-2,3-bis-phenyl-plumbolyl) and $\left[\mathrm{Li}(\text { thf })_{4}\{(\operatorname{cod}) \mathrm{Rh}\}-\right.$ $\left.\left(\eta^{5}-\mathrm{L}^{\mathrm{Pb}}\right)\right],{ }^{20}$ and another inverted sandwich $\mathrm{Rh}$ complex $\left[\{(\operatorname{cod}) \mathrm{Rh}\}_{2}\left(\mu, \eta^{5}-\mathrm{L}^{\mathrm{Pb}}\right)\right]^{20}$ were reported. Related trimetallic triple-decker species with three distinct deck motifs have remained elusive. Generating such trimetallic triple-decker complexes with a plumbole deck is the aim of our work.

In our first attempt to synthesize a lead-containing polyphosphide, the dilithioplumbole $\left[\operatorname{Li}_{2}(\operatorname{thf})_{2}\left(\mu, \eta^{5}-\mathrm{L}^{\mathrm{Pb}}\right)\right]^{18}$ was reacted with white phosphorus $\left(\mathrm{P}_{4}\right)$ in toluene at room temperature for $16 \mathrm{~h}$ (Scheme 1). The colour of the solution turned from green to colourless concomitant with the precipitation of grey metallic powder. After filtration and concentration of the toluene solution, colourless crystals of the reaction product were isolated in $60 \%$ yield, which was identified as phospholyl lithium 1. Its structure was determined by NMR spectroscopy and X-ray crystallography. The molecular structure of $\mathbf{1}$ (Fig. 2) shows that the phosphorus atom has replaced the lead atom in the fivemembered ring and one lithium atom is $\eta^{5}$-coordinated at the phospholyl moiety. In addition, one THF molecule is coordinated to the $\mathrm{Li}$ cation. Interestingly, a series of differently substituted phospholyl lithium species have been prepared by the group of $\mathrm{Xi}$ directly from $\mathrm{P}_{4}$ and organodilithium reagents. ${ }^{21}$ The ${ }^{31} \mathrm{P}\left\{{ }^{1} \mathrm{H}\right\}$ NMR shift of $\mathbf{1}$ at $\mathbf{1 5 4 . 1} \mathrm{ppm}$ is in good agreement with the signals reported for the other phospholyl lithium species containing silyl groups (141.3-165.2 ppm). ${ }^{21 a}$

Since the attempted preparation of Pb-polyphosphides was unsuccessful using $\mathrm{P}_{4}$ as phosphorus source, we tested the reaction between $\left[\mathrm{Li}_{2}(\mathrm{thf})_{2}\left(\mu, \eta^{5}-\mathrm{L}^{\mathrm{Pb}}\right)\right]^{18}$ and $\left[\mathrm{Cp}{ }^{*} \mathrm{Fe}\left(\eta^{5}-\mathrm{P}_{5}\right)\right]^{9}$ (Scheme 2). Stirring the two starting materials at room temperature in benzene led to an immediate color change from green to dark blue and formation of the triple-decker complex $\left[\left\{\mathrm{Cp} * \mathrm{Fe}\left(\eta^{4}-\mathrm{P}_{5}\right)\right\} \mathrm{Li}\left(\eta^{5}-\mathrm{L}^{\mathrm{Pb}}\right) \mathrm{Li}(\text { thf })\right]_{2}$ (2) (Scheme 2). During the reaction, formally, the plumbole dianion is oxidized to the neutral heterocycle, while $\left[\mathrm{Cp} * \mathrm{Fe}\left(\eta^{5}-\mathrm{P}_{5}\right)\right]$ is reduced to
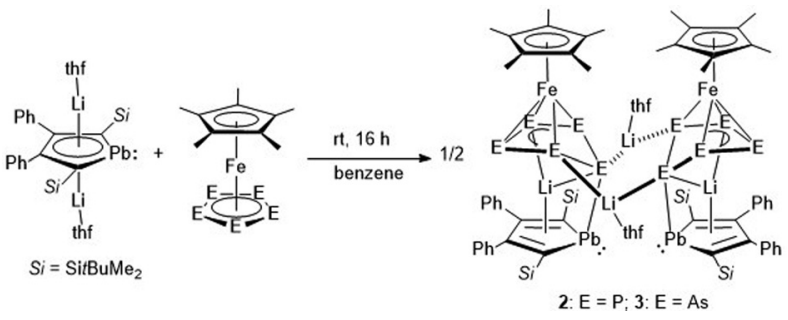

Scheme 2 Synthesis of complexes $\mathbf{2}$ and $\mathbf{3}$.

$\left\{\mathrm{Cp}{ }^{*} \mathrm{Fe}\left(\eta^{5}-\mathrm{P}_{5}\right)\right\}^{2-}$ and both fragments are combined in a novel triple-decker scaffold. Complex 2 was crystallized from benzene in $41 \%$ yield (Fig. 2). The molecular structure of 2 in the solid state consists of two identical triple-decker motifs, generated by rotation around the crystallographic $C_{2}$ axis. These two units are interconnected through $\mathrm{Li} 2$ and Li2' ${ }^{\prime}$. Each triple-decker motif is constituted by a $\left\{\mathrm{Cp}^{*} \mathrm{Fe}\left(\eta^{4}-\mathrm{P}_{5}\right)\right\}$ unit, which is $\pi$-coordinated by a $\left\{\left(\mathrm{L}^{\mathrm{Pb}}\right) \mathrm{Li}\right\}$ fragment. The $\pi$-coordinated $\mathrm{Li}$ atoms are in closer spatial proximity to the plumbole moiety of 2 (Li-C: $2.261-2.337 \AA$, $\mathrm{Li}-\mathrm{Pb}=2.794 \AA$ ) than in the dilithioplumbole ( $\mathrm{Li}-\mathrm{C} \quad 2.281-2.448 \AA$ A, $\mathrm{Li}-\mathrm{Pb}$ 2.854-2.897 ̊). ${ }^{18}$ Due to the two-electron reduction, the cyclo- $\mathrm{P}_{5}$ fragment loses its planarity and adopts an envelope-shaped conformation, which coordinates in an $\eta^{4}$ fashion to the $\left\{\mathrm{Cp}^{*} \mathrm{Fe}\right\}$ fragment. ${ }^{12 d, f, 22}$ The resulting $\mathrm{P}_{4}(\mathrm{P} 1-\mathrm{P} 2-\mathrm{P} 3-\mathrm{P} 4)$ unit is nearly planar (torsion angle $=1.9^{\circ}$ ), P5 deviates from the plane and is coordinated to $\mathrm{Pb}$ with a distance of $2.8357(9) \AA$, which is slightly longer than the $\mathrm{Pb}-\mathrm{P}$ bonds in the cage complexes $\left[\mathrm{Pb}_{6}\left(\mathrm{PSiiPr}_{3}\right)_{6}\right]$ and $\left[\mathrm{Pb}_{7}(t \mathrm{BuP})_{7}\right]$ $(2.666-2.754 \AA){ }^{23}$ After reduction and coordination toward Li and $\mathrm{Pb}$, the P-P bond distances (2.149-2.197 $\AA$ ) are only slightly longer than those in the starting material (average $2.120 \AA$ ), indicating partial double bond character of these bonds. ${ }^{24}$ The plumbole maintained planarity with the sum of the internal angles being $537.5^{\circ}$. In contrast to the dilithioplumbole with no $\mathrm{C}-\mathrm{C}$ bond alternation in the ring, ${ }^{18}$ the $\mathrm{C}-\mathrm{C}$ bond lengths in 2 alter remarkably $(\mathrm{C} 1-\mathrm{C} 2=1.355(4), \mathrm{C} 2-\mathrm{C} 3=1.515(4)$ and $\mathrm{C} 3-\mathrm{C} 4=1.364(4) \AA)$, rendering the heterocycle non-aromatic but the expected 1,3-diene character. Similar geometry was found in the base-stabilized plumbacyclopentadienylidenes. ${ }^{25}$

The ${ }^{1} \mathrm{H}$ NMR spectrum of 2 in $\mathrm{C}_{6} \mathrm{D}_{6}$ reveals four sharp singlet signals corresponding to the $\mathrm{SitBuMe}_{2}$ group and the $\mathrm{Cp}^{*}$ moiety. In the ${ }^{13} \mathrm{C}\left\{{ }^{1} \mathrm{H}\right\}$ NMR spectrum, signals assignable to
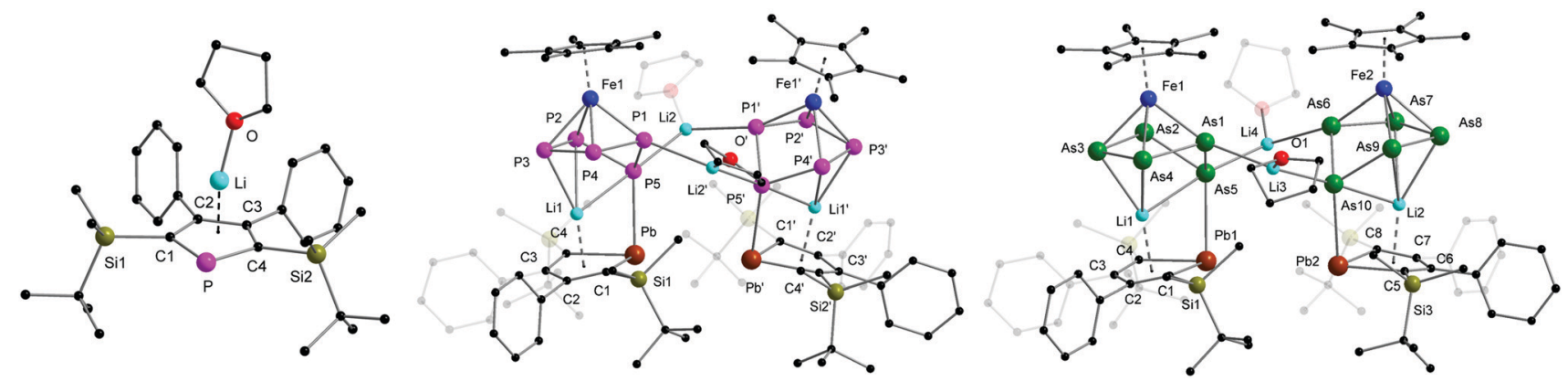

Fig. 2 Molecular structures of 1, 2 and 3. All hydrogen atoms and non-coordinating solvent molecules are omitted for clarity. For selected bond distances and angles, see ESI.‡ 
the plumbole ring $\mathrm{C}_{\alpha}$ atom (212.5 $\mathrm{ppm}$ ) is only marginally shifted compared to that of the starting material (213.5 ppm), whereas the signal for the $\mathrm{C}_{\beta}$ atom $(172.8 \mathrm{ppm})$ is observed in a much lower field compared to the dilithioplumbole (159.4 ppm). The two different Li atoms observed in the solid state (sandwich type and bridging type) do not scramble in solution because two different signals are observed in the ${ }^{7} \mathrm{Li}\left\{{ }^{1} \mathrm{H}\right\}$ NMR spectrum at 1.2 and $-3.9 \mathrm{ppm}$. The former signal is assignable to the bridging $\mathrm{Li}$ atom and the latter one to the $\pi$-coordinated Li nucleus, corroborated by DFT computations. ${ }^{18}$ At room temperature, the ${ }^{31} \mathrm{P}\left\{{ }^{1} \mathrm{H}\right\}$ NMR of 2 shows two broad signals at $42.4 \mathrm{ppm}$ and $18.4 \mathrm{ppm}$ and a doublet of doublets at $-14.3 \mathrm{ppm}$. When low temperature VT NMR studies in toluene$d_{8}$ were carried out (see Fig. S17, ESI $\$$ ), an apparent $\mathrm{AA}^{\prime} \mathrm{MM}^{\prime} \mathrm{X}$ spin system, typical for envelope-shaped $\mathrm{P}_{5}$ systems, could be observed. ${ }^{12 e, 13 a}$ The ${ }^{207} \mathrm{~Pb}$ NMR spectrum exhibits one resonance at $2587 \mathrm{ppm}$, bearing good similarity to the dilithioplumbole (2573 ppm). ${ }^{18}$

Given the aforementioned reactivity with $\left[\mathrm{Cp}^{*} \mathrm{Fe}\left(\eta^{5}-\mathrm{P}_{5}\right)\right]$, we turned to its heavier arsenic analogue $\left[\mathrm{Cp}{ }^{*} \mathrm{Fe}\left(\eta^{5}-\mathrm{As}_{5}\right)\right] .^{10}$ In general, the reactivity of the latter one is significantly less explored, and reduction often resulted in mixtures of different arsenic-rich species. ${ }^{26-28}$ As an example, the reduction of $\left[\mathrm{Cp}^{*} \mathrm{Fe}\left(\eta^{5}-\mathrm{P}_{5}\right)\right]$ with $\mathrm{KH}$ afforded $\left[\mathrm{K}(\mathrm{dme})_{2} \mathrm{~K}(\mathrm{dme})\right]\left[\left(\mathrm{Cp}^{*} \mathrm{Fe}\right)_{2}\left(\mu, \eta^{4: 4}-\mathrm{P}_{10}\right)\right]$ only, ${ }^{12 d}$ while the reaction of $\left[\mathrm{Cp}^{*} \mathrm{Fe}\left(\eta^{5}-\mathrm{As}_{5}\right)\right]$ with $\mathrm{KH}$ resulted in a mixture of different polyarsenic $\operatorname{As}_{n}(n=4,10,14,18)$ scaffolds stabilized by $\left\{\mathrm{Cp}^{*} \mathrm{Fe}\right\}$ fragments. ${ }^{26}$ Herein, we were interested whether the reduction of the heavier arsenic congener $\left[\mathrm{Cp}^{*} \mathrm{Fe}\left(\eta^{5}-\mathrm{As}_{5}\right)\right]$ with the dilithioplumbole will proceed in a similar way as that of its lighter phosphorus derivative or will rather generate other polyarsenides. The reaction between $\left[\mathrm{Li}_{2}(\mathrm{thf})_{2}\left(\mu, \eta^{5}-\mathrm{L}^{\mathrm{Pb}}\right)\right]^{18}$ and $\left[\mathrm{Cp} * \mathrm{Fe}\left(\eta^{5}-\mathrm{As}_{5}\right)\right]^{10}$ was carried out in a similar manner as with its phosphorus analogues. As a result, brown crystals of the reaction product $\left[\left\{\mathrm{Cp}^{*} \mathrm{Fe}\left(\eta^{4}-\mathrm{As}_{5}\right)\right\} \mathrm{Li}\left(\eta^{5} \mathrm{~L}^{\mathrm{Pb}}\right) \mathrm{Li}(\mathrm{thf})\right]_{2}$ (3) (Scheme 2), suitable for X-ray structural analysis were obtained in $48 \%$ yield. Analogous to the reduction of $\left[\mathrm{Cp}^{*} \mathrm{Fe}\left(\eta^{5}-\mathrm{P}_{5}\right)\right]$, the two-electron reduction of the cyclo$\mathrm{As}_{5}$ unit was observed (Fig. 2). Although, 3 forms a similar dimeric triple-decker structure as $\mathbf{2}$ in the solid state, there are some slight differences, as the two triple-decker subunits are symmetryindependent. The lithium atoms, which are part of the tripledecker structure (Li1 and Li2) are $\eta^{4}$-coordinated by the cyclo-As units with interatomic distances ranging from 2.630(6) to 3.001(7) $\AA$, whereas in compound 2 , the corresponding lithium atoms are $\eta^{3}$ coordinated by the cyclo- $\mathrm{P}_{5}$ unit with interatomic P-Li distances ranging from 2.484(6) to 2.794(6) $\AA$. In these units, As5 and As10 are bent out of the $\mathrm{As}_{4}$ planes with an angle of $54.4^{\circ}$ and $55.4^{\circ}$, respectively. The envelope-shaped $\mathrm{As}_{5}$ moiety and the As-As bond distances (2.376-2.442 $\AA$ ) are similar to that observed in the f-element polyarsenide complexes. ${ }^{13 a, 22}$ The $\mathrm{Pb}$-As distances of 2.9171(5) $\AA$ (Pb1-As5) and 2.9132(4) $\AA$ (Pb2-As10) are longer than those in the cage complex $\left[\mathrm{PbAsSiiPr}_{3}\right]_{6}(2.794-2.837 \AA){ }^{29}$ indicating a weaker interaction between $\mathrm{Pb}$ and As. It is noteworthy to mention that molecular compounds with $\mathrm{Pb}-\mathrm{As}$ bonds are scare and only known in some cage complexes..$^{29,30}$

To gain deeper insight into the electronic structure of complexes 2 and 3 , we have performed density functional

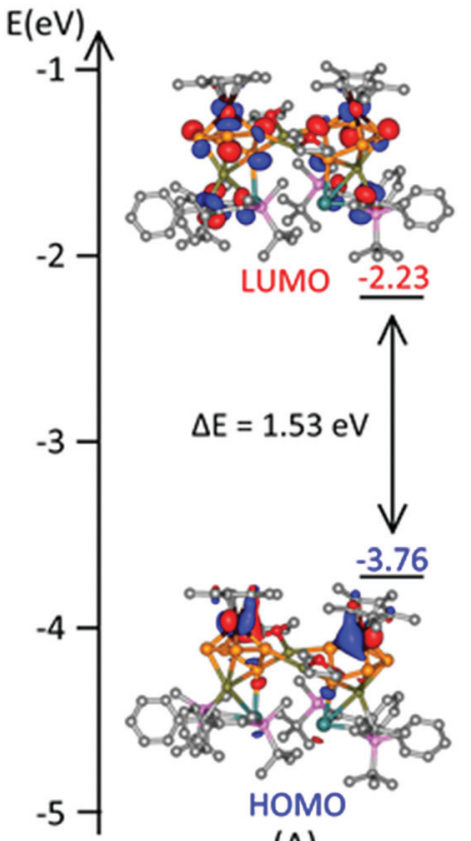

(A)
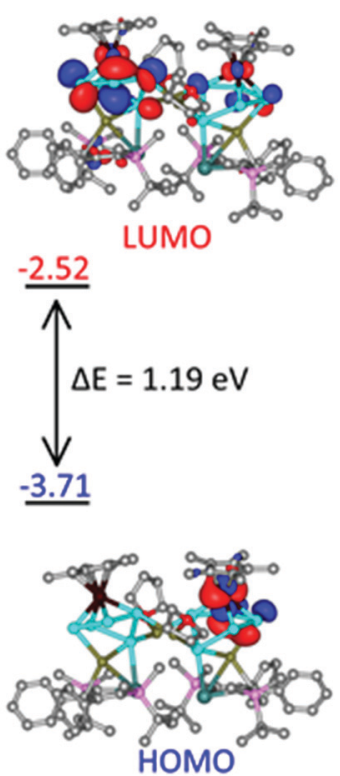

(B)
Fig. 3 Energy diagrams and selected Kohn-Sham orbitals (side view) of UB97D/6-31G**/DEF2SVP optimized geometry of (A) complex 2 and (B) complex 3.

theory (DFT) calculations (for details, see ESI $\$$ ). The geometries of complexes $\mathbf{2}$ and $\mathbf{3}$ were optimized in the gas phase without any constraints (see Fig. S24, ESI $\ddagger$ ) and retained the original structural motifs. We have also examined the Kohn Sham orbitals to get more details of electronic structure of our novel triple-decker complexes (Fig. 3 and Fig. S25, S26, ESI‡). HOMO to HOMO-3 orbitals are mainly localized on iron and phosphorus centers having very small energy difference between them. While HOMO-4 is localized on plumbole ring with larger component on $\mathrm{Pb}$ with an energy difference of $0.45 \mathrm{eV}$, LUMOs are localized on the plumbole and $\mathrm{P}_{5}$ rings. Similarly, in complex 3 HOMO to HOMO-3 orbitals are mainly localized on iron and arsenic centers with an energy span of $0.54 \mathrm{eV}$ while the LUMOs are localized on the plumbole and $\mathrm{As}_{5}$ rings.

We have also examined the topologies of $\mathrm{Pb}-\mathrm{P} 5$ and $\mathrm{Pb}-\mathrm{As} 5$ linkage within the framework by Bader theory. ${ }^{31}$ We were able to identify the bond critical point (BCP) for both $\mathrm{Pb}-\mathrm{P} 5$ and $\mathrm{Pb}-\mathrm{As} 5$ interactions in complex 2 and 3 , respectively. The electron density $[\rho(r)]$ values between the $\mathrm{Pb}-\mathrm{P} 5$ and $\mathrm{Pb}-\mathrm{As} 5$ pairs for complexes 2 and 3 are 0.041 and 0.038 a.u., which suggest electrostatic bonding with modest covalent contributions. The Laplacian of the electron density $\left[\nabla^{2} \rho(r)\right]$ was found to be in the range of $0.049-0.056$.

In summary, we have shown a new and straightforward reaction pathway to generate unprecedented trinuclear triple-decker complexes by the reduction of pentaphosphaferrocene and pentaarsaferrocene with the dilithioplumbole. Both triple-decker complexes comprise an envelope-shaped $\mathrm{E}_{5}$ polypnictogen middle deck and a planar lead-containing heterocycle as the lower deck revealing the first $\mathrm{Pb}-\mathrm{Fe}-\mathrm{Li}$ heterotrimetallic triple-decker polypnictogenides. 
These results spotlight the use of the heaviest group 14 metallole dianion as a unique two-electron reducing agent to generate previously unknown structural motifs.

This work was supported by the Deutsche Forschungsgemeinschaft (DFG) with the project No. 470309834 (Ro2008/21-1 and Sche384/45-1). A. S. acknowledges funding from the DFGfunded transregional collaborative research center SFB/TRR 88 "Cooperative Effects in Homo and Heterometallic Complexes (3MET)”.

\section{Conflicts of interest}

There are no conflicts of interest.

\section{References}

1 (a) T. J. Kealy and P. L. Pauson, Nature, 1951, 168, 1039-1040; (b) E. O. Fischer and W. Pfab, Z. Naturforsch., B: J. Chem. Sci., 1952, 7, 377-379; (c) G. Wilkinson, M. Rosenblum, M. C. Whiting and R. B. Woodward, J. Am. Chem. Soc., 1952, 74, 2125-2126.

2 E. O. Fischer and W. Hafner, Z. Naturforsch., B: Anorg. Chem., Org. Chem., Biochem., Biophys., Biol., 1955, 10, 665-668.

3 (a) A. N. Nesmeyanov and N. S. Kochetkova, Russ. Chem. Rev., 1974, 43, 710-715; (b) D. Bravo-Zhivotovskii, R. Dobrovetsky, D. Nemirovsky, V. Molev, M. Bendikov, G. Molev, M. Botoshansky and Y. Apeloig, Angew. Chem., Int. Ed., 2008, 47, 4343-4345.

4 (a) C. Janiak and H. Schumann, in Advances in Organometallic Chemistry, ed. F. G. A. Stone and R. West, Academic Press, 1991, vol. 33, pp. 291-393; (b) H. Bauer, A. Glöckner, A. C. Tagne Kuate, S. Schäfer, Y. Sun, M. Freytag, M. Tamm, M. D. Walter and H. Sitzmann, Dalton Trans., 2014, 43, 15818-15828.

5 (a) A. Salzer and H. Werner, Angew. Chem., Int. Ed. Engl., 1972, 11, 930-932; (b) H. Werner and A. Salzer, Synth. React. Inorg. Met.-Org. Chem., 1972, 2, 239-248.

6 (a) H. Werner, Angew. Chem., Int. Ed. Engl., 1977, 16, 1-9; (b) W. Siebert, Russ. Chem. Rev., 1991, 60, 784-791; (c) G. E. Herberich, U. Englert, F. Marken and P. Hofmann, Organometallics, 1993, 12, 4039-4045; (d) A. R. Kudinov, A. A. Fil'chikov, P. V. Petrovskii and M. I. Rybinskaya, Russ. Chem. Bull., 1999, 48, 1352-1355; (e) V. Beck and D. O'Hare, J. Organomet. Chem., 2004, 689, 3920-3938.

7 A. L. Rheingold, M. J. Foley and P. J. Sullivan, J. Am. Chem. Soc., 1982, 104, 4727-4729.

8 O. J. Scherer, J. Schwalb, G. Wolmershäuser, W. Kaim and R. Gross, Angew. Chem., Int. Ed. Engl., 1986, 25, 363-364.

9 O. J. Scherer and T. Brück, Angew. Chem., Int. Ed. Engl., 1987, 26, 59.

10 O. J. Scherer, C. Blath and G. Wolmershäuser, J. Organomet. Chem., 1990, 387, C21-C24.

11 E. Peresypkina, A. Virovets and M. Scheer, Coord. Chem. Rev., 2021, 446, 213995.

12 (a) R. F. Winter and W. E. Geiger, Organometallics, 1999, 18, 1827-1833; (b) T. Li, J. Wiecko, N. A. Pushkarevsky, M. T. Gamer, R. Köppe, S. N. Konchenko, M. Scheer and P. W. Roesky, Angew. Chem., Int. Ed., 2011, 50, 9491-9495; (c) T. Li, M. T. Gamer, M. Scheer, S. N. Konchenko and P. W. Roesky, Chem. Commun., 2013, 49, 2183-2185; (d) M. V. Butovskiy, G. Balázs, M. Bodensteiner, E. V. Peresypkina, A. V. Virovets, J. Sutter and M. Scheer, Angew. Chem., Int. Ed., 2013, 52, 2972-2976; (e) R. Yadav, T. Simler, S. Reichl, B. Goswami, C. Schoo, R. Köppe, M. Scheer and
P. W. Roesky, J. Am. Chem. Soc., 2020, 142, 1190-1195; $(f)$ R. Yadav, T. Simler, B. Goswami, C. Schoo, R. Köppe, S. Dey and P. Roesky, Angew. Chem., Int. Ed., 2020, 132, 9530-9534.

13 (a) N. Reinfandt, N. Michenfelder, C. Schoo, R. Yadav, S. Reichl, S. N. Konchenko, A. N. Unterreiner, M. Scheer and P. W. Roesky, Chem. - Eur. J., 2021, 27, 7862-7871; (b) R. Yadav, B. Goswami, T. Simler, C. Schoo, S. Reichl, M. Scheer and P. W. Roesky, Chem. Commun., 2020, 56, 10207-10210; (c) R. Yadav, M. Weber, A. K. Singh, L. Münzfeld, J. Gramüller, R. M. Gschwind, M. Scheer and P. W. Roesky, Chem. - Eur. J., 2021, 14128-14137; (d) M. E. Moussa, M. Fleischmann, G. Balázs, A. V. Virovets, E. Peresypkina, P. A. Shelyganov, M. Seidl, S. Reichl and M. Scheer, Chem. - Eur. J., 2021, 27, 9742-9747.

14 (a) M. Piesch and M. Scheer, Organometallics, 2020, 39, 4247-4252; (b) M. Detzel, G. Friedrich, O. J. Scherer and G. Wolmershäuser, Angew. Chem., Int. Ed. Engl., 1995, 34, 1321-1323; (c) M. Detzel, T. Mohr, O. J. Scherer and G. Wolmershäuser, Angew. Chem., Int. Ed. Engl., 1994, 33, 1110-1112; (d) O. J. Scherer, S. Weigel and G. Wolmershäuser, Chem. - Eur. J., 1998, 4, 1910-1916; (e) K. Mast, J. Meiers, O. J. Scherer and G. Wolmershäuser, Z. Anorg. Allg. Chem., 1999, 625, 70-74; $(f)$ M. Piesch, F. Dielmann, S. Reichl and M. Scheer, Chem. - Eur. J., 2020, 26, 1518-1524.

15 M. Detzel, T. Mohr, O. J. Scherer and G. Wolmershäuser, Angew. Chem., Int. Ed. Engl., 1994, 33, 1110-1112.

16 (a) M. Saito and M. Yoshioka, Coord. Chem. Rev., 2005, 249, 765-780; (b) M. Saito, Acc. Chem. Res., 2018, 51, 160-169; (c) J. Wei, W.-X. Zhang and Z. Xi, Chem. Sci., 2018, 9, 560-568.

17 (a) T. Kuwabara, J.-D. Guo, S. Nagase, T. Sasamori, N. Tokitoh and M. Saito, J. Am. Chem. Soc., 2014, 136, 13059-13064; (b) M. Saito, N. Matsunaga, J. Hamada, S. Furukawa, M. Minoura, S. Wegner, J. Barthel and C. Janiak, Dalton Trans., 2018, 47, 8892-8896.

18 M. Saito, M. Nakada, T. Kuwabara and M. Minoura, Chem. Commun., 2015, 51, 4674-4676.

19 M. Nakada, T. Kuwabara, S. Furukawa, M. Hada, M. Minoura and M. Saito, Chem. Sci., 2017, 8, 3092-3097.

20 M. Saito, M. Nakada, T. Kuwabara, R. Owada, S. Furukawa, R. Narayanan, M. Abe, M. Hada, K. Tanaka and Y. Yamamoto, Organometallics, 2019, 38, 3099-3103.

21 (a) L. Xu, Y. Chi, S. Du, W.-X. Zhang and Z. Xi, Angew. Chem., Int. Ed., 2016, 55, 9187-9190; (b) S. Du, W.-X. Zhang and Z. Xi, Organometallics, 2018, 37, 2018-2022.

22 C. Schoo, S. Bestgen, M. Schmidt, S. N. Konchenko, M. Scheer and P. W. Roesky, Chem. Commun., 2016, 52, 13217-13220.

23 S. Almstätter, M. Eberl, G. Balázs, M. Bodensteiner and M. Scheer, Z. Anorg. Allg. Chem., 2012, 638, 1739-1745.

24 P. Pyykkö and M. Atsumi, Chem. - Eur. J., 2009, 15, 12770-12779.

25 M. Saito, T. Akiba, M. Kaneko, T. Kawamura, M. Abe, M. Hada and M. Minoura, Chem. - Eur. J., 2013, 19, 16946-16953.

26 M. Schmidt, D. Konieczny, E. V. Peresypkina, A. V. Virovets, G. Balázs, M. Bodensteiner, F. Riedlberger, H. Krauss and M. Scheer, Angew. Chem., Int. Ed., 2017, 56, 7307-7311.

$27 \mathrm{~T} \mathrm{Li}$, J. Wiecko, N. A. Pushkarevsky, M. T. Gamer, R. Köppe, S. N. Konchenko, M. Scheer and P. W. Roesky, Angew. Chem., Int. Ed., 2011, 50, 9491-9495.

28 N. Arleth, M. T. Gamer, R. Köppe, S. N. Konchenko, M. Fleischmann and M. Scheer, Angew. Chem.. Int. Ed., 2016, 55, 1557-1560.

29 C. von Hänisch and D. Nikolova, Z. Anorg. Allg. Chem., 2004, 630, 345-346.

30 (a) S. Traut and C. von Hänisch, Chem. Commun., 2010, 46, 1538-1540; (b) S. Traut and C. von Hänisch, Z. Anorg. Allg. Chem., 2011, 637, 1777-1783.

31 R. F. W. Bader, Chem. Rev., 1991, 91, 893-928. 